Atmos. Chem. Phys., 10, 3309-3319, 2010

www.atmos-chem-phys.net/10/3309/2010/

(C) Author(s) 2010. This work is distributed under

the Creative Commons Attribution 3.0 License.

\title{
Overview of mercury measurements in the Antarctic troposphere
}

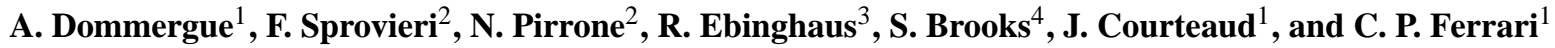 \\ ${ }^{1}$ Laboratoire de Glaciologie et Géophysique de l'Environnement, CNRS, UMR 5183 - Université Joseph Fourier Grenoble, \\ 54 Rue Molière, 38400 St Martin d'Hères, France \\ ${ }^{2}$ CNR- Institute on Atmospheric Pollution Research, Division of Rende, Italy \\ ${ }^{3}$ GKSS Research Centre Geesthacht, Institute for Coastal Research, Max-Planck-Str. 1, 21502 Geesthacht, Germany \\ ${ }^{4}$ NOAA Air Resources Laboratory, Atmospheric Turbulence and Diffusion Division, Oak Ridge, USA
}

Received: 27 November 2009 - Published in Atmos. Chem. Phys. Discuss.: 11 December 2009

Revised: 19 March 2010 - Accepted: 30 March 2010 - Published: 7 April 2010

\begin{abstract}
Polar ecosystems are considered to be the last pristine environments of the earth relatively uninfluenced by human activities. Antarctica in particular, compared to the Arctic is considered to be even less affected by any kind of anthropogenic influences. Once contaminants reach the Polar Regions, their lifetime in the troposphere depends on local removal processes. Atmospheric mercury, in particular, has unique characteristics that include longrange transport to Polar Regions and the transformation to more toxic and water-soluble compounds that may potentially become bioavailable. These chemical-physical properties have placed mercury on the priority list of an increasing number of International, European and National conventions, and agreements, aimed at the protection of the ecosystems including human health (i.e. GEO, UNEP, AMAP, UNECE, HELCOM, OSPAR). This interest, in turn, stimulates a significant amount of research including measurements of gaseous elemental mercury reaction rate constant with atmospheric oxidants, experimental and modelling studies in order to understand the cycling of mercury in Polar Regions, and its impact to these ecosystems. Special attention in terms of contamination of Polar Regions is paid to the consequences of the springtime phenomena, referred to as "Atmospheric Mercury Depletion Events" (AMDEs), during which elemental mercury through a series of photochemicallyinitiated reactions involving halogens, may be converted to a reactive form that may accumulate in polar coastal, or sea ice, ecosystems. The discovery of the AMDEs, first noted in the Arctic, has also been observed at both poles and was initially considered to result in an important net input of atmospheric mercury into the polar surfaces. However, recent
\end{abstract}

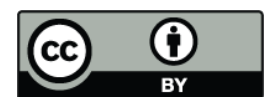

Correspondence to: A. Dommergue (dommergue@lgge.obs.ujf-grenoble.fr) studies point out that complex processes take place after deposition that may result in less significant net-inputs from the atmosphere since a fraction, sometimes significant, of deposited mercury may be recycled. Therefore, the contribution of this unique reactivity occurring in polar atmospheres to the global budget of atmospheric mercury, and the role played by snow and ice surfaces of these regions, are important issues. This paper presents a review of atmospheric mercury studies conducted in the Antarctic troposphere, both at coastal locations and on the Antarctic Plateau since 1985. Our current understanding of atmospheric reactivity in this region is also presented.

\section{Introduction}

Antarctica is often considered as a giant cold trap where many long-lived species or atmospheric oxidation products are deposited and buried in the ice fields (Eisele et al., 2008). This vast continent of 14 million $\mathrm{km}^{2}$, almost entirely covered by ice, revealed surprising findings on the biogeochemical cycle of major elements such as sulfur and nitrogen (Eisele et al., 2008 and references therein). Antarctica is a place of choice for atmospheric studies, because it has no real primary sources, except volcanoes, and is uninhabited except for a few scientific stations. However, due to a combination of logistical issues, harsh meteorological conditions, studies are de facto scarce. Polar Regions, like other regions of the planet, are impacted by long-range transport of man-made emissions of mercury $(\mathrm{Hg})$. Mercury is mostly transported as gaseous elemental mercury $\mathrm{Hg}(0)$, which has a lifetime of about 1 year in the troposphere. In Antarctica, gross mercury input is probably controlled by the Southern Hemisphere emissions. While Northern Hemisphere

Published by Copernicus Publications on behalf of the European Geosciences Union. 
$\mathrm{Hg}(0)$ concentrations have likely been decreasing (Faïn et al., 2009) following the decrease of Northern Hemisphere emissions over the last decades, Southern Hemisphere emissions increased from 1990 to 1995, and have stayed roughly constant since 1995. From 1990 to 1995 Africa emissions increased from 200 to 400 tons/year, Australia from 50 to 100 tons/year, and South America from 55 to 80 tons/year (Pacyna et al., 2006; Lindberg et al., 2007).

The discovery made in Alert (Canada) in 1995 (Schroeder et al., 1998), which revealed that elemental gaseous mercury is oxidized and deposited onto arctic snow surfaces more rapidly than anywhere else due to a phenomenon called Atmospheric Mercury Depletion Events (AMDEs), has sparked considerable interest in the research community. While the tropospheric reactivity of mercury in the Arctic is more and more documented only a few attempts were made to study the $\mathrm{Hg}$ cycle in the Southern Polar Regions. Following Schroeder et al. (1998) study, AMDEs were observed in Coastal Antarctica after polar sunrise at Neumayer and Terra Nova Bay (Ebinghaus et al., 2002b; Sprovieri et al., 2002).

The study of the Hg cycling in Antarctica is first necessary to understand and follow the extent of the contamination within these ecosystems. Mercury concentrations in biota of some Arctic areas are known to have increased with time (Dietz et al., 2009) and to be rather high. In Antarctica, available data on $\mathrm{Hg}$ concentrations in water, sediments, phytoplankton, macroalgae, krill and several species of benthic invertebrates compiled by Bargagli et al. (2008) indicate that there is no enhanced bioavailability of $\mathrm{Hg}$ in the Southern Ocean food web. However, recent studies showed an enhanced $\mathrm{Hg}$ bioaccumulation in terrestrial ecosystem samples collected close to Terra Nova Bay (Bargagli et al., 2005), suggesting that local deposition events of $\mathrm{Hg}$ may impact these ecosystems.

Second, the role of the Antarctic continent and its influence on the global geochemical cycle of mercury is unclear today, and is certainly under evaluated by current models (Selin et al., 2007). Ice and snow cover are known to play an important role in the reactivity of the overlying atmosphere (Dominé and Shepson, 2002). For example, there is new evidence suggesting that nitrogen, in the form of nitrate, may undergo multiple recycling within a given photochemical season (Davis et al., 2008).

Finally, the $3 \mathrm{~km}$ of ice that lies below the surface of the Antarctic continent is also used as an archive to retrieve the content of ancient atmospheres over hundreds of thousands of years (Jitaru et al., 2009). It was shown that Hg deposition in surface snows was greater during the coldest climatic stages, coincident with the highest atmospheric dust loads. A possible explanation is that the oxidation of gaseous mercury by sea-salt-derived halogens occurred in the cold atmosphere. An understanding of atmospheric chemistry of $\mathrm{Hg}$ is therefore relevant because it provides one of the critical inputs for evaluating the air-to-snow "transfer function" for a chemical specie.
This article presents a current state of $\mathrm{Hg}$ measurements in the Antarctic troposphere. Most of the research activities are today located in the Northern Hemisphere with long-term data for only a few sites. The Antarctic regions have not been extensively monitored yet, and only sporadic measurements have been made. However, an effort has been first made to study the processes of AMDEs on coastal sites. More recently, the Antarctic Plateau has become a new focus of attention. All these efforts show that we currently underestimate the role of this continent on the global cycle of mercury, and that it offers broad perspectives in terms of new findings on $\mathrm{Hg}$ cycling.

\section{Methodology}

\subsection{Definitions}

Gaseous elemental mercury, Reactive Gaseous Mercury (RGM) and Particle associated mercury (PHg) are the most commonly measured and monitored fractions. Considering these three atmospheric species, $\operatorname{Hg}(0)$ is maybe the only component that is easily and accurately measured in the field. RGM and PHg are operationally defined and thus measurements from different sites may be complex to inter-compare. In some cases, Total Gaseous Mercury (TGM) may be provided. It generally refers to the sum of $\mathrm{Hg}(0)$ and RGM.

\subsection{Instrumentation}

A summary of the instrumentation and of the experimental set-up is provided in Table 1. All recent (i.e. after 2000) $\mathrm{Hg}(0)$ measurements presented here were performed using a commercially available unit Tekran 2537A. This automated instrument allows for continuous measurement of $\mathrm{Hg}(0)$ in ambient air with a high sensitivity using gold trap amalgamation, thermal desorption and detection by Atomic Fluorescence Spectroscopy (AFS). The Tekran 2537A performs automated recalibrations for $\mathrm{Hg}(0)$ using an internal permeation source, which provides approximately $1 \mathrm{pg} / \mathrm{s}$ of $\mathrm{Hg}(0)$ at $50{ }^{\circ} \mathrm{C}$ into a zero airstream. This permeation sources is periodically recalibrated by manual injections of $\mathrm{Hg}(0)$ vapor using a microsyringe. Intercomparison campaigns have shown good agreement using different Tekran 2537 units (Aspmo et al., 2005). In Polar Regions, some researchers report ambient air collected with this method as TGM which includes both the $\mathrm{Hg}(0)$ and RGM species (Ebinghaus et al., 2002b). However, if a filter (soda lime trap for instance) is placed at the inlet of the sample line, it is most likely that RGM is removed and thus only $\mathrm{Hg}(0)$ is collected (Steffen et al., 2002; Steffen et al., 2008). Using these instruments a detection limit of $0.1 \mathrm{ng} \mathrm{m}^{-3}$ can be achieved.

Older $\mathrm{Hg}(0)$ or TGM measurements (De Mora et al., 1993) were achieved by drawing air through collectors containing silvered sand. The tubes were sealed and analyzed within a 
Table 1. A summary of some analytical parameters for atmospheric $\mathrm{Hg}$ species measurements.

\begin{tabular}{llllll}
\hline Instrument & $\mathrm{Hg}$ Species & Typical Duration;flow rate & Detection limit & Precision & Reference \\
\hline Tekran 2537A & $\mathrm{Hg}(0) / \mathrm{TGM}$ & $5 \mathrm{~min} ; 1.5 \mathrm{~L} \mathrm{~min}^{-1}$ & $<0.1 \mathrm{ng} \mathrm{m}^{-3}$ & $2 \%$ & Tekran Corp. \\
Silver gilded sand traps & $\mathrm{TGM}$ & $24-48 \mathrm{~h} ; 1 \mathrm{~L} \mathrm{~min}^{-1}$ & $0.05 \mathrm{ng} \mathrm{m}^{-3}$ & $4 \%$ & (De Mora et al., 1993) \\
Tekran 1130 Front end & $\mathrm{RGM}$ & $2 \mathrm{~h} ; 10 \mathrm{~L} \mathrm{~min}^{-1}$ & $3.1 \mathrm{pg} \mathrm{m}^{-3}$ & $15 \%$ & (Landis et al., 2002) \\
Tekran 1135 Front end & $\mathrm{PHg}$ & $2 \mathrm{~h} ; 10 \mathrm{~L} \mathrm{~min}^{-1}$ & $\sim 3 \mathrm{pg} \mathrm{m}^{-3}$ & $\sim 15 \%$ & Our estimates \\
AES-Mini-Traps-quartz & $\mathrm{PHg}$ & $48 \mathrm{~h} ; 3.5-4.5 \mathrm{~L} \mathrm{~min}^{-1}$ & $\sim 2 \mathrm{pg} \mathrm{m}^{-3}$ & $\sim 20 \%$ & (Lu et al., 1998; Temme et al., 2003) \\
Whatman filters & $\mathrm{PHg}$ & $24 \mathrm{~h} ; 1.1 \mathrm{~m}^{3} \mathrm{~min}^{-1}$ & Not reported & $\sim 20 \%$ & (Arimoto et al., 2004) \\
Micro-Quartz fibre filters & $\mathrm{PHg}$ & $48 \mathrm{~h} ; 4.5 \mathrm{~L} \mathrm{~min}^{-1}$ & $\sim 2 \mathrm{pg} \mathrm{m}^{-3}$ & $\sim 20 \%$ & (Sprovieri and Pirrone, 2000) \\
\hline
\end{tabular}

few days of collection by photoacoustic spectroscopy. Unfortunately, the measurement technique used by De Mora et al. (1993) has, to our knowledge, not been compared with modern instrumentation. Therefore data obtained using this technique should be cautiously considered even though the range of concentration that was obtained is coherent with recent measurements obtained using automated sensors. Intercomparison campaigns using automated and manual trap methods have however shown comparable results (Ebinghaus et al., 1999; Munthe et al., 2001) to the Tekran 2537.

RGM concentration are measured with a Tekran 1130 mercury speciation unit, which gives the Tekran 2537A mercury vapor analyzer the ability to concurrently monitor both $\mathrm{Hg}(0)$ and RGM. A KCl-coated quartz annular denuder captures reactive gaseous mercury while allowing elemental mercury to pass through. The denuder is heated to $500^{\circ} \mathrm{C}$ in a stream of $\mathrm{Hg}$ free air. The thermally-released $\mathrm{Hg}$ is passed over a pyrolysis chamber $\left(\sim 800^{\circ} \mathrm{C}\right)$. The RGM is thermally decomposed to $\mathrm{Hg}(0)$ and is transferred to the Tekran 2537A. RGM is usually detected in the low $\mathrm{pg} \mathrm{m}^{-3}$ concentration range. A direct primary calibration method for RGM does not yet exist. In addition, $\mathrm{KCl}$ denuders are known to collect $\mathrm{HgCl}_{2}$ and/or $\mathrm{HgBr}_{2}$ (Steffen et al., 2008), and the chemical speciation of RGM has yet to be determined. Therefore RGM values should be carefully considered.

$\mathrm{PHg}$ values were obtained by different methods. Measurements at Neumayer (Ebinghaus et al., 2002b; Temme et al., 2003) were done using an AESminiSamplR developed by the Meteorological Service of Canada (Lu et al., 1998). This miniaturized device consists of a quartz tube with a 6-mm quartz fiber filter disk, served as both particulate trap and pyrolyzer for airborne particulate mercury species. At Terra Nova Bay (Sprovieri and Pirrone, 2000; Sprovieri et al., 2002), PHg concentrations were obtained by collecting airborne particles on micro-quartz fibre filters mounted in a quartz tube for $48 \mathrm{~h}$ at a flow-rate of $4.5 \mathrm{LPM}$ and analyzed by AFS. Brooks et al. (2008a, b) used the Tekran 1135, a commercially-available unit. The Tekran 1135 is used together with the Model 1130 Speciation Unit and the Model 2537 Mercury Analyzer. RGM is captured in the 1130 unit (see description above) and the fine fraction particulate bound mercury species are then trapped onto a unique quartz regenerable filter. Arimoto et al. (2004) samples were collected with high-volume sampling on Whatman filters (Whatman Ltd., Maidstone, UK). Filters were digested following the protocol outlined in Landing et al. (1998) and analyzed by inductively coupled plasma mass spectrometry (ICPMS). Similar to RGM, PHg measurements have to be carefully considered because of the lack of intercomparability. Intercomparison exercises realized using different automated and manual techniques (Munthe et al., 2001; Aspmo et al., 2005) have shown the need of substantial improvement in the characterization of oxidized mercury species, and a direct primary calibration method for PHg. The fraction of particulate mercury as determined by automated instrument might differ significantly from the fraction measured using filter collection.

\subsection{Atmospheric measurements in cold regions}

Mercury speciation sampling methods are similar to methods conducted around the world with exceptions made for the extreme cold, the blowing snow layer, the high altitude of the polar ice caps, and the high magnitude of mercury fluxes in and out of the surface snow.

Care must be taken to (1) ensure that flow volumes and residence times are appropriate for the speciation of mercury into the 3 components, (2) prevent unintended mercury absorption in the sampling lines, and (3) ensure near $100 \%$ collection efficiency onto the pre-concentrating gold cartridges. Atop the high-altitude polar plateau item (1) requires matching the volume flow to a 0.1 second residence time over the KCl-coated annular denuder. At foggy coastal sites item (2) requires that dry air must be used to flush the system, otherwise the iodated carbon canisters (used to remove all mercury from the flush air) can potential introduce iodine into the flush stream, where it can unintentional oxidize gaseous elemental mercury. In all locations item (3) requires a high purity inert carrier gas, and a sampling location (such as a clean air sector) where contamination is minimized.

Under very cold conditions the heated sample lines should be kept fully external from the air-conditioned area, 
Table 2. Summary of atmospheric mercury measurements performed at different Antarctic locations from 1985 to 2009 . NA: data not available; BDL: concentrations below detection limit.

\begin{tabular}{|c|c|c|c|c|c|c|c|}
\hline \multirow[t]{2}{*}{ Measurement sites } & \multirow[t]{2}{*}{ Period } & \multirow[t]{2}{*}{ Methods } & \multirow[t]{2}{*}{ Species } & \multicolumn{3}{|c|}{ Statistical Parameters in ng.m ${ }^{-3}$} & \multirow[t]{2}{*}{ References } \\
\hline & & & & Mean \pm Std dev. & Min. & Max. & \\
\hline $\begin{array}{l}\text { Lake Vanda } \\
77^{\circ} 33^{\prime} \mathrm{S} 161^{\circ} 37^{\prime} \mathrm{E}\end{array}$ & Dec 1985 & $\begin{array}{l}\text { Manual-silvered/gilded } \\
\text { sand collectors }\end{array}$ & TGM & $0.23 \pm \mathrm{NA}$ & NA & NA & (De Mora et al., 1993) \\
\hline Scott Base & 1987 & Manual-silvered/gilded & TGM & $0.52 \pm 0.14$ & 0.16 & 0.83 & (De Mora et al., 1993) \\
\hline $77^{\circ} 51^{\prime} \mathrm{S} 166^{\circ} 46^{\prime} \mathrm{E}$ & 1988 & sand collectors & TGM & $0.60 \pm 0.40$ & 0.02 & 1.85 & \\
\hline $\begin{array}{l}\text { Arrival Heights } \\
77^{\circ} 11^{\prime} \mathrm{S} 166^{\circ} 40^{\prime} \mathrm{E}\end{array}$ & 1989 & $\begin{array}{l}\text { Manual-silvered/gilded } \\
\text { sand collectors }\end{array}$ & TGM & $0.52 \pm 0.16$ & 0.11 & 0.78 & (De Mora et al., 1993) \\
\hline Neumayer & $2000-2001$ & Tekran 2537A; 1130 and & TGM & $1.08 \pm 0.29$ & 0.27 & 2.34 & (Ebinghaus et al., \\
\hline $70^{\circ} 39^{\prime} \mathrm{S} 08^{\circ} 15^{\prime} \mathrm{W}$ & & $\begin{array}{l}\text { KCl-Coated Annular De- } \\
\text { nuders; } \\
\text { AESmini-Traps }\end{array}$ & $\begin{array}{l}\mathrm{Hg}(0) \\
\mathrm{RGM} \\
\mathrm{PHg}\end{array}$ & $\begin{array}{l}0.99 \pm 0.27 \\
\text { NA } \\
\text { NA }\end{array}$ & $\begin{array}{l}0.16 \\
5 \times 10^{-3} \\
15 \times 10^{-3}\end{array}$ & $\begin{array}{l}1.89 \\
\sim 300.10^{-3} \\
120 \times 10^{-3}\end{array}$ & $\begin{array}{l}\text { 2002b; } \\
\text { Temme et al., 2003) }\end{array}$ \\
\hline Terra Nova Bay & 1999-2001 & Tekran 2537A; 1130 and & TGM & $0.81 \pm 0.1$ & 0.5 & 0.9 & (Sprovieri and Pirrone, \\
\hline $74^{\circ} 41^{\prime} \mathrm{S}, 164^{\circ} 07^{\prime} \mathrm{E}$ & & $\begin{array}{l}\text { KCl-Coated Annular De- } \\
\text { nuders; Gold-mini Traps } \\
\text { Filter collection }\end{array}$ & $\begin{array}{l}\mathrm{Hg}(0) \\
\mathrm{RGM} \\
\mathrm{PHg}\end{array}$ & $\begin{array}{l}0.9 \pm 0.3 \\
(116 \pm 78) \times 10^{-3} \\
(12 \pm 6) \times 10^{-3}\end{array}$ & $\begin{array}{l}0.29 \\
\sim 11.10^{-3} \\
\sim 4.10^{-3}\end{array}$ & $\begin{array}{l}2.3 \\
334 \times 10^{-3} \\
20 \times 10^{-3}\end{array}$ & $\begin{array}{l}2000 ; \\
\text { Sprovieri et al., 2002) }\end{array}$ \\
\hline $\begin{array}{l}\text { South Pole } \\
90^{\circ} 00^{\prime} \mathrm{S}\end{array}$ & $\begin{array}{l}\text { Nov-Dec 2003; } \\
\text { Nov } 2005 \\
\text { Nov 2000- } \\
\text { Dec } 2001\end{array}$ & $\begin{array}{l}\text { Tekran } 2537 \mathrm{~A} ; 1130,1135 \\
\text { Filter collection }\end{array}$ & $\begin{array}{l}\mathrm{Hg}(0) \\
\mathrm{RGM} \\
\mathrm{PHg} \\
\mathrm{PHg}\end{array}$ & $\begin{array}{l}0.54 \pm 0.19 \\
(344 \pm 151) \times 10^{-3} \\
(224 \pm 119) \times 10^{-3} \\
(166 \pm 147) \times 10^{-3}\end{array}$ & $\begin{array}{l}0.24 \\
95 \times 10^{-3} \\
71 \times 10^{-3} \\
11 \times 10^{-3}\end{array}$ & $\begin{array}{l}0.82 \\
705 \times 10^{-3} \\
660 \times 10^{-3} \\
827 \times 10^{-3}\end{array}$ & $\begin{array}{l}\text { (Brooks et al., 2008a) } \\
\text { (Arimoto et al., 2004) }\end{array}$ \\
\hline $\begin{array}{l}\text { McMurdo } \\
77^{\circ} 13^{\prime} \mathrm{S} 166^{\circ} 45^{\prime} \mathrm{E}\end{array}$ & Oct-Nov 2003 & Tekran 2537A; 1130, 1135 & $\begin{array}{l}\mathrm{Hg}(0) \\
\mathrm{RGM} \\
\mathrm{PHg}\end{array}$ & $\begin{array}{l}1.20 \pm 1.08 \\
(116 \pm 45) \times 10^{-3} \\
(49 \pm 36) \times 10^{-3}\end{array}$ & $\begin{array}{l}\text { BDL } \\
29 \times 10^{-3} \\
5 \times 10^{-3}\end{array}$ & $\begin{array}{l}11.16 \\
275 \times 10^{-3} \\
182 \times 10^{-3}\end{array}$ & (Brooks et al., 2008b) \\
\hline $\begin{array}{l}\text { Concordia } \\
75^{\circ} 06^{\prime} \mathrm{S} 123^{\circ} 20^{\prime} \mathrm{E}\end{array}$ & Jan 2009 & Tekran 2537A & $\mathrm{Hg}(0)$ & $0.85 \pm 0.46$ & $\mathrm{BDL}$ & 2.2 & (Courteaud et al., 2010) \\
\hline
\end{tabular}

otherwise the temperature change between interior and exterior portions will induce hot/cold zones and mercury absorption/desorption at the tubing walls. The exterior front-end cases and the exterior sampling lines should have robust insulation and heating systems that will not significantly vary the set temperatures regardless of weather conditions. The inlet position must be placed sufficiently above the blowing snow layer, but remain within the lowest $10 \%$ of the atmospheric boundary layer, which may be as shallow as a few 10 's of meters.

\section{Results and discussion}

\subsection{Atmospheric mercury in the Antarctic}

Antarctica and the Southern Ocean are located in a remote region, with no indigenous human population and no industrial activity. Human activity is minimal and localized. Human presence in the region largely consists of scientific investigations and logistical operations in support of these investigations. The greatest human impact can be expected where research is carried out at long-term stations, with populations typically less than 100 people. Far from anthropogenic emissions, and isolated by the circumpolar vortex, only the longest-lived of the global atmospheric contaminants, such as $\mathrm{Hg}(0)$, make their way to the Antarctica Plateau. The overwhelming majority of anthropogenic $\mathrm{Hg}$ loading to the environment and biota derives from global, rather than local, inputs. Antarctica is characterized by a vast, cold, dry, high-altitude polar plateau ( $>2400 \mathrm{~m})$, and a coastal region where the seasonal freezing and melting of sea ice surrounding the continent is the Earth's largest seasonal energy exchange event. This vast freezing of sea ice liberates sea salt bromine $(\mathrm{Br})$, chlorine $(\mathrm{Cl})$, and iodine (I). The Polar Plateau chemistry is dominated, during the annual sunlit period, by an oxidizing canopy of $\mathrm{OH}, \mathrm{O}_{3}$, and $\mathrm{HO}_{2}$ (Eisele et al., 2008).

\subsubsection{A summary of available $\mathrm{Hg}$ species measurements}

Few field experiments dedicated to mercury have been performed in Antarctica compared to those carried out in the Arctic. Mercury measurements performed at different locations within the Antarctic region are reported in Table 2 and shown in Fig. 1. The first baseline data for the concentration and speciation of atmospheric mercury in Antarctica were reported by De Mora et al. (1993). Mercury measurements were carried out at three sampling locations in the vicinity of McMurdo throughout 1985 and 1989. In particular, a preliminary study was carried out on the frozen surface of Lake Vanda $\left(77^{\circ} 33^{\prime} \mathrm{S}, 161^{\circ} 37^{\prime} \mathrm{E}\right)$ in the Wright Valley during December 1985 . While obviously limited, the data were interesting and suggested that TGM concentrations in Antarctica were substantially lower than those observed elsewhere $\left(0.23 \mathrm{ng} \mathrm{m}^{-3}\right)$. Therefore, further studies were conducted throughout 1987 and 1988 at Scott Base $\left(77^{\circ} 51^{\prime} \mathrm{S} 166^{\circ} 46^{\prime} \mathrm{E}\right)$ and during 1989 at Arrival Heights $\left(77^{\circ} 11^{\prime} \mathrm{S}, 166^{\circ} 40^{\prime} \mathrm{E}\right)$, also on Ross Island. The mean TGM for 1987 was $0.52 \pm 0.14 \mathrm{ng} \mathrm{m}^{-3}$, whereas the corresponding 


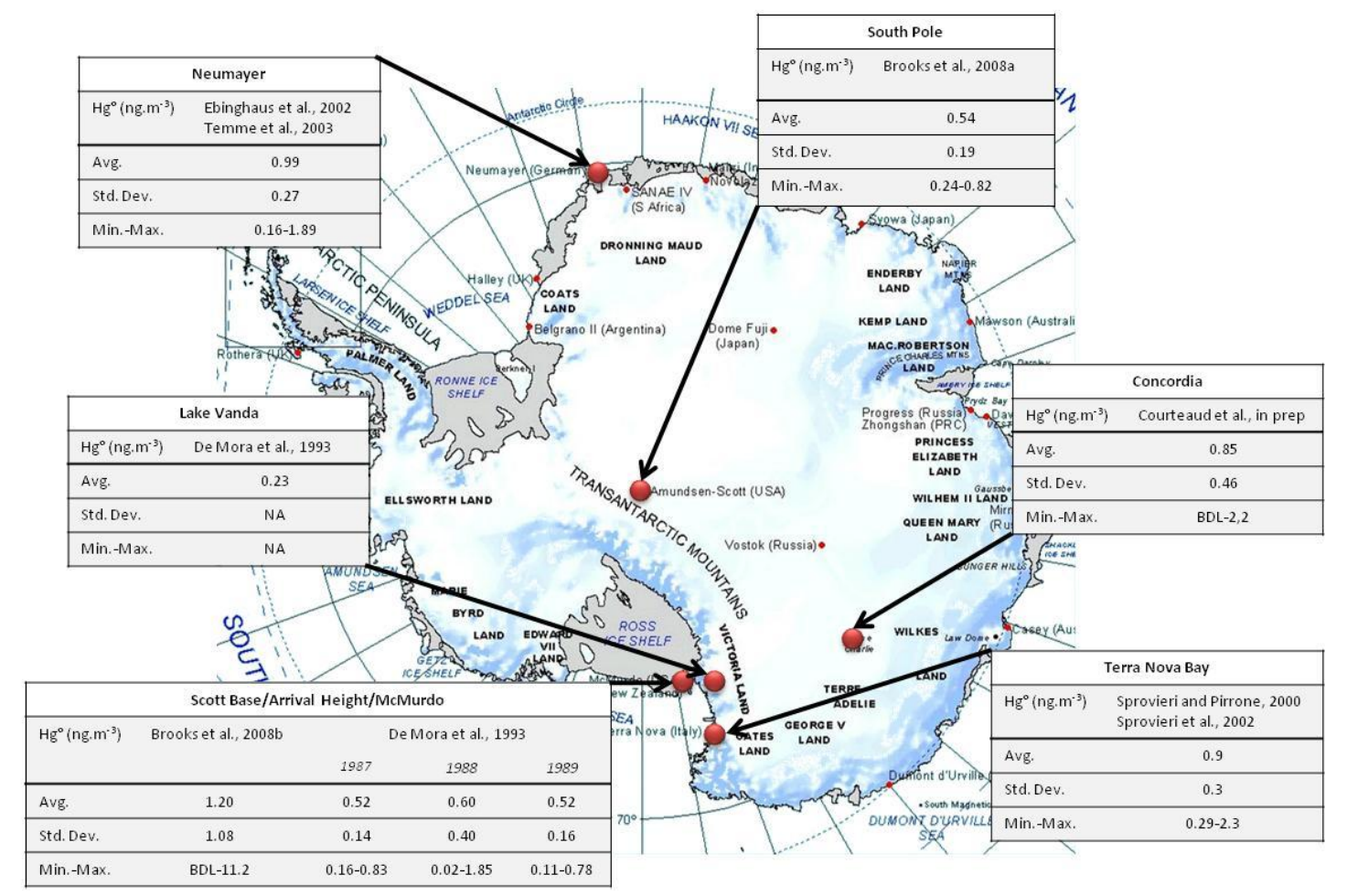

Fig. 1. Measurement sites for gaseous atmospheric mercury in Antarctica.

1988 value was $0.60 \pm 0.40 \mathrm{ng} \mathrm{m}^{-3}$. At the third site, mean TGM value was $0.52 \pm 0.16 \mathrm{ng} \mathrm{m}^{-3}$. Recent advances in mercury measurements included a gain in sensitivity and automated high- frequency continuous measurements. It gave the opportunity to extend the monitoring of atmospheric mercury reactivity, which has been made in several coastal locations at the Italian Antarctic Station in Terra Nova Bay (Sprovieri and Pirrone, 2000; Sprovieri et al., 2002), the German Research Station Neumayer (Ebinghaus et al., 2002b; Temme et al., 2003), the US Station McMurdo (Brooks et al., 2008b). Two sites on the Antarctic Plateau have also been explored at the US South Pole Station (Arimoto et al., 2004; Brooks et al., 2008a) and more recently at the French-Italian Concordia Base (Courteaud et al., 2010).

\subsubsection{Atmospheric reactivity at Antarctic coastal sites}

In order to better understand the chemical processes that may act to enhance the capture of $\mathrm{Hg}$ from the global atmosphere and its deleterious impact on Antarctic ecosystems, high-temporal-resolution $\mathrm{Hg}$ measurements were performed. The first annual time series of ground-level TGM concentrations in the Antarctic to investigate the occurrence of possible AMDEs in Southern Polar Regions were obtained by Ebinghaus et al. (2002b) at the German Research Station at Neumayer. In that study AMDEs were observed during Antarctic springtime 2000 with minimum daily average concentrations of about $0.1 \mathrm{ng} \mathrm{m}^{-3}$. Similar springtime mercury dynamics was also observed at two other coastal locations at Terra Nova Bay (Sprovieri et al., 2002) and McMurdo (Brooks et al., 2008b). The high-resolution data were compared with existing data sets of AMDEs in the Arctic and revealed similarities between the temporal and quantitative sequence of AMDEs after polar sunrise. During early springtime (August-October), TGM and ozone $\left(\mathrm{O}_{3}\right)$ were positively correlated (Ebinghaus et al., 2002b) as in the Arctic boundary layer (Schroeder et al., 1998), even if the ozone depletion events at Neumayer are less frequent, and shorter (Lehrer, 1999). The positive correlation between $\mathrm{Hg}(0)$ and $\mathrm{O}_{3}$ concentrations near the coasts during Antarctic sunrise means that the depletion of $\mathrm{Hg}(0)$ also depends on photochemicallyproduced oxidants. Friess (2001) detected enhancements of atmospheric bromine compound, $\mathrm{BrO}$ in the lower troposphere, during the same period, using Differential Optical Absorption Spectroscopy (DOAS). Ebinghaus et al. (2002b) also found that AMDEs at Neumayer station coincided with enhanced column densities of $\mathrm{BrO}$ for this area, derived from measurements by the satellite-borne GOME (Richter et al., 1998) indicating regions and magnitudes of bromine emissions. As illustrated in Figure 2, the $\mathrm{BrO}$ in the nearsurface air (lowest $1 \mathrm{~km}$ ) is superimposed on the satellite column measurements, where the stratospheric and upper tropospheric concentrations are assumed to be relatively uniform. Thus the $\sim 30 \%$ enhancements from the background 


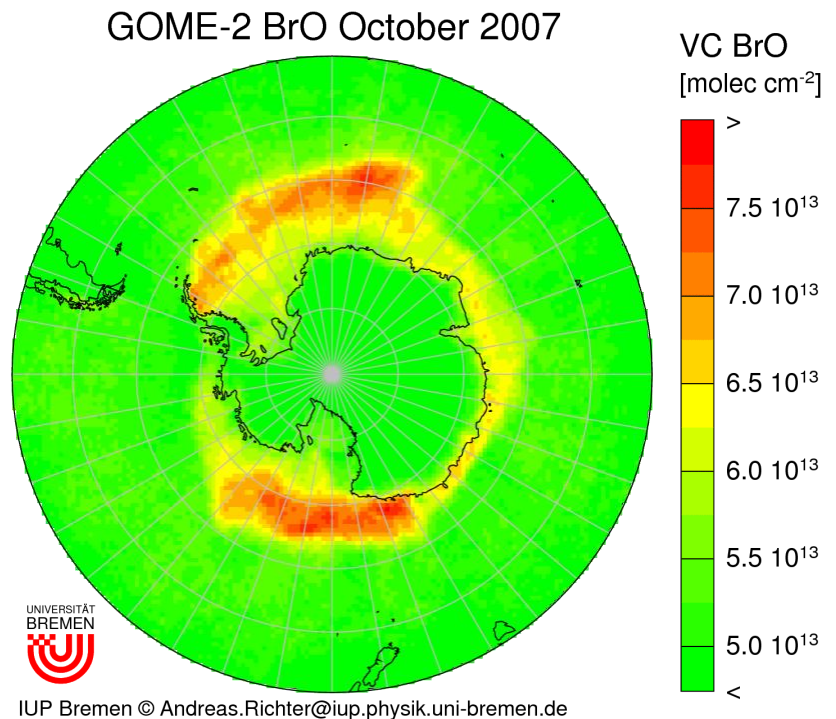

Fig. 2. An example of higher $\mathrm{BrO}$ concentrations (in red) observed each year around the Antarctic continent during springtime. This monthly average map shows total $\mathrm{BrO}$ retrieved from measurements of the GOME-2 instrument in October 2007. The columns include both the stratospheric contribution (about $5 \times 10 \mathrm{E}^{13}$ molec $\mathrm{cm}^{-2}$ ) and the tropospheric BrO amounts. (Richter et al., 1998).

$\mathrm{BrO}$ to the highest column concentrations represents significant $\mathrm{BrO}$ concentrations in the lowest $1 \mathrm{~km}$ of the atmospheric column. Air masses at ground level coming from the sea ice surface, accompanied by $\mathrm{BrO}$ enhancements, could be a necessary condition for the AMDEs in Coastal Antarctica. Atmospheric mercury and ozone depletion events are noticeable along the sea ice edges where polynyas and flaw leads (waterway opening between pack ice and fast ice) provide frequently freezing sea ice surfaces and the formation of frost flowers or brine slush as a potential source of atmospheric bromine (Kaleschke et al., 2004; Jones et al., 2006). The bromine source is still open to some debate and other sources may coexist such as sea-salt aerosols (Vogt et al., 1996), snow (McConnell et al., 1992) or young ice with sea salts (Simpson et al., 2007) and salty blowing snow (Yang et al., 2008). Based on the available data, we are inclined to hypothesize that in Antarctic coastal areas the enhanced oxidation of $\operatorname{Hg}(0)$ is similar to that which has been observed in the Arctic and speculate here that it similar involves $\mathrm{BrO}$ or other halogen-containing radical or compounds. Among reactive halogen species thermodynamically favoured to oxidize $\mathrm{Hg}(0)$ to form RGM and/or PHg in the gaseous phase, $\mathrm{Cl}_{2}, \mathrm{Br}_{2}$, and $\mathrm{BrCl}$ appear to be most probable (Fan and Jacob, 1992; Vogt et al., 1996; Richter et al., 1998). Molecular $\mathrm{Cl}_{2}, \mathrm{Br}_{2}$, and $\mathrm{BrCl}$ are, however, not likely to produce in situ RGM formation because they rapidly undergo photolysis in sunlight conditions (Vogt et al., 1996; Richter et al., 1998). Therefore, springtime photochemical dissociation of the molecular forms of the halogens $\left(\mathrm{Br}_{2}\right.$ and/or $\left.\mathrm{Cl}_{2}\right)$ results in the corresponding atomic species production, $\mathrm{Br} / \mathrm{Cl}$, which may also directly oxidize $\mathrm{Hg}(0)$ to $\mathrm{Hg}(\mathrm{I})$ to produce unidentified species such as $\mathrm{HgX}^{*}$ (Lindberg et al., 2002; Calvert and Lindberg, 2003; Goodsite et al., 2004; Maron et al., 2008; Castro et al., 2009) which may then be further oxidized to $\mathrm{Hg}$ (II) (Hynes et al., 2009). In the case of iodine, Saiz-Lopez et al. (2008) measured bromine oxide, $\mathrm{BrO}$, and iodine oxide, IO, simultaneously within the atmospheric boundary layer near the coastal site of Halley Station. Both species were present throughout the annual sunlit period and exhibit similar seasonal cycles and concentrations. Their measurement of the springtime peak of iodine oxide (20 pptv) remains the highest concentration recorded anywhere in the ambient atmosphere. The combination of high levels of bromine and iodine could significantly enhance ozone and $\mathrm{Hg}(0)$ depletion within the boundary layer (Saiz-Lopez et al., 2007; SaizLopez et al., 2008). The relative influences of the halogens, $\mathrm{Br}, \mathrm{Cl}$, and $\mathrm{I}$, on $\mathrm{Hg}(0)$ oxidation and deposition are difficult to determine, as their marine sources and reactivity with $\mathrm{Hg}(0)$ appear to be similar.

Both at the Italian Antarctic Station in Terra Nova Bay - where opposite trends between TGM concentrations and the quantity of $\mathrm{Hg}$ associated with particulate matter was previously observed (Sprovieri and Pirrone, 2000) - and at the German Research Station at Neumayer, high RGM concentrations (i.e. $>300 \mathrm{pg} \mathrm{m}^{-3}$ ) were recorded comparable to those directly observed by anthropogenic $\mathrm{Hg}$ sources (Sprovieri et al., 2002; Temme et al., 2003). Interestingly, these high levels were measured in the absence of simultaneous ozone and $\mathrm{Hg}(0)$ depletion events during summertime. In fact, either no correlation or a significant negative correlation was rather observed between $\mathrm{Hg}(0)$ and $\mathrm{O}_{3}$ (Sprovieri et al., 2002; Temme et al., 2003). The $\mathrm{Hg}(0)$ depletions recorded in January show no significant correlation to any additional parameters that were measured (Temme et al., 2003). The very high RGM concentrations at both coastal sites could be influenced by the local production of oxidized gaseous mercury species over the Antarctic continent or by shelf ice during polar summer. This suggests that the oxidation of $\operatorname{Hg}(0)$ to RGM, and a concurrent production of $\mathrm{O}_{3}$, has already occurred before the air parcels were advected to the sampling site. Temme et al. (2003) proposed a gas-phase oxidation of $\mathrm{Hg}(0)$ by potential oxidants (i.e. $\mathrm{OH}, \mathrm{HO}_{2}$ ) associated with high levels of NO. These oxidants result from photodenitrification processes in the snow-pack (Jones et al., 2008) which may maintain the high RGM concentrations that were observed. Therefore, additional atmospheric measurements of potential precursor compounds and isentropic trajectory calculations are required to potentially ascertain the reaction mechanism and origin of the air masses reaching the measurements locations where these high RGM levels are observed during the Antarctic summer.

On coastal sites high levels of oxidized $\mathrm{Hg}$ species up to $300 \mathrm{pg} \mathrm{m}^{-3}$ have been observed. These species are deposited onto coastal snowpacks leading to high total $\mathrm{Hg}$ 


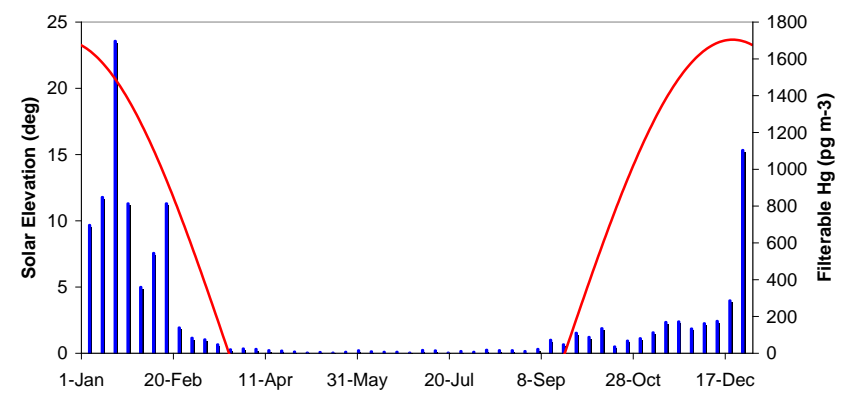

Fig. 3. Weekly averages of total filterable (the sum of RGM and $\mathrm{PHg}$ ) mercury concentrations (bars) collected as $\mathrm{Hg}$ on high volume filters, and the annual solar elevation angles (line) at South Pole Station. High volume filters allow $\mathrm{Hg}(0)$ is pass but collect $\mathrm{PHg}$ and a significant portion of the RGM (after Brooks et al., 2008a).

concentrations around $40-430 \mathrm{ng} \mathrm{L}^{-1}$ in the surface snow (Brooks et al., 2008b) and around 10-40 ng L-1 onto adjacent glaciers of the McMurdo Dry Valleys (Witherow and Lyons, 2008). The post depositional fate of these compounds is not fully explored however a fraction is reemitted following their photoreduction as evidenced by some atmospheric $\operatorname{Hg}(0)$ peaks measured at McMurdo (Brooks et al., 2008b).

\subsubsection{Reactivity on the Antarctic Plateau}

On the Antarctic Plateau where the snowpack is perennial and distant from halogen emissions from freezing sea ice sources, oxidized mercury species were first reported by Arimoto et al. (2004) from high volume filter results at the South Pole station clean air sector. They report elevated PHg levels up to $150 \mathrm{pg} \mathrm{m}^{-3}$ from November to January. More recently Brooks et al. (2008a) combined mercury measurements in snow and air, with vertical mercury flux measurements at the South Pole. It shows that filterable $\mathrm{Hg}$ concentrations ( $\mathrm{RGM}+\mathrm{PHg}$ ) are totally absent during the dark fall and winter seasons (Fig. 3), implying that sunlight is a requirement to produce these oxidized mercury species. Moreover, polar sunrise ( $\sim$ September 21 at the South Pole) heralds negligible mercury oxidation. Mercury oxidation rates only begin to peak around mid-summer with maximum values $\sim 1$ February when extremely high oxidized mercury concentrations were measured in the near-surface air (e.g., RGM + PHg; $\left.100-1000 \mathrm{pg} \mathrm{m}^{-3}\right)$. It indicates a delay between the reemerging sunlight and the $\operatorname{Hg}(0)$ transport, and the oxidizing canopy that likely drives the atmospheric chemical production of oxidized mercury species. This peak $\mathrm{Hg}$ oxidation period (January-February) roughly corresponds to the annual photochemical peak cycles of nitrogen oxides, $\mathrm{OH}$ and $\mathrm{HO}_{2}$ (Mauldin III et al., 2004; Davis et al., 2008). Another recent study at Concordia (Courteaud et al., 2010) showed that $\mathrm{Hg}(0)$ ground levels were both affected by the snowpack recycling and the variations of the boundary layer height. Con- trarily to South Pole station, the diurnal radiation cycle at Concordia significantly modulates the sensible heat flux during the course of the day leading to an increase of the boundary layer height during the afternoon (Legrand et al., 2009). A significant local $\mathrm{Hg}(0)$ production (through photochemical processes occurring at the snow surface) was measured when a thin boundary layer $(<50 \mathrm{~m})$ was maintained. Later, the strong increase of the boundary layer height may lead to a significant decrease of $\operatorname{Hg}(0)$ levels diluted by strongly $\mathrm{Hg}(0)$-depleted air.

The deposition of oxidized mercury is massive leading to hundreds of $\mathrm{ng} \mathrm{L}^{-1}$ of $\mathrm{Hg}$ (II) in the surface snow and in deeper layers of the snowpack measured at both Concordia and South Pole.

The observations on the Polar Plateau showed atmospheric oxidized mercury depositing to the snow pack, subsequent photoreduction, and emissions of $\mathrm{Hg}(0)$ from the surface. Given the dry conditions of the Antarctic Polar Plateau (burial/snowfall rate is $\sim 10 \mathrm{~cm} /$ year) only $\sim 10 \%$ of the deposited mercury is deeply buried (sequestered), resulting in some 60 metric tons $\mathrm{Hg}$ annually based on concentrations and flux rates presented in Brooks et al. (2008a). This dynamic mercury cycle on the Polar Plateau appears to be driven by Southern Hemisphere Hg emissions, photochemistry, and the related oxidizing canopy enshrouding the entire high plateau. However mechanisms of reactivity are not fully understood.

\subsection{Tropospheric reactivity in the Antarctic vs. the Arctic}

Slemr et al. (2003) estimated a Southern Hemisphere background $\mathrm{Hg}(0)$ concentration of $1.2 \mathrm{ng} \mathrm{m}^{-3}$, lower than background concentrations measured in the Northern Hemisphere around $1.7 \mathrm{ng} \mathrm{m}^{-3}$ (Ebinghaus et al., 2002a). In the Arctic, a mean $\mathrm{Hg}(0)$ value around $1.5-1.6 \mathrm{ng} \mathrm{m}^{-3}$ is observed at monitoring sites such as Alert, Canada (Steffen et al., 2005). Though there is an obvious need of long-term monitoring data at coastal sites in Antarctica, a mean annual value around $1.0 \mathrm{ng} \mathrm{m}^{-3}$ might be inferred from current $\mathrm{Hg}(0)$ measurements. The higher $\operatorname{Hg}(0)$ concentrations observed in the Arctic when compared to the Antarctica clearly indicate the different chemical composition of the troposphere as a result of the location of the measurements areas. In fact, the Arctic is surrounded by populated continents from which pollution is released and transported to the north. In contrast, the Antarctic is entirely surrounded by the Southern Ocean and is far from any anthropogenic emissions. In particular, fluxes of mercury to the atmosphere, mainly from anthropogenic and continental sources in the Northern Hemisphere (particularly from Eurasia and North America in late winter and spring), are greater than those in the Southern Hemisphere, and higher atmospheric concentrations are found in the North than the South. Finally, the reactivity of $\mathrm{Hg}(0)$ (in particular oxidation processes) might be more intense in 
the Antarctic than in the Arctic, however the reactivity is not well evaluated and intensive atmospheric campaigns focused on atmospheric $\mathrm{Hg}$ and other oxidants should be carried out.

Similar to the Arctic, atmospheric mercury and ozone depletion events are most noticeable along the sea ice edges. Both spatial and temporal coverage of $\mathrm{Hg}$ measurements in the Antarctic are very limited. The behaviour of mercury species may be associated with a number of reactive chemicals and reactions that take place in the atmosphere after polar sunrise. The tropospheric chemistry of the polar areas is distinctly different than in the other parts of the earth due to natural differences of meteorological and solar radiation conditions. During the winter months, in total lack of solar radiation, temperature and humidity conditions are very low, so the vertical mixing of the lower stratified Antarctic troposphere is hindered. The direct consequence is that the abundance of photochemically labile compounds will rise, while the level of photochemical products will be low. During spring and summer, solar radiation is present $24 \mathrm{~h}$ a day and under sunlight conditions, the elevated concentrations of reactants present in the Antarctic atmosphere can initiate a sequence of atmospheric chemical transformations often different than other latitudes. It can be anticipated that in the polar troposphere, free radical precursors that build up in the darkness of the polar winter begin to photodissociate and the resulting gas phase radicals may play a fundamental role in the elemental gas phase mercury decrease seen in Antarctica and in the Arctic. Although in the Arctic the highest RGM concentrations were found during AMDEs, elevated concentrations were found at Barrow (Alaska) extending to the end of the annual snowmelt (Lindberg et al., 2002). Snowmelt is more limited in the Antarctic, even at coastal sites, than it is in the Arctic, which suggests that the snowpack is directly involved in maintaining high RGM concentrations.

While Arctic and Antarctic coastal sites experience episodic mercury depletion events which occur predominantly in the late winter and early spring, the elevated altitude Polar Plateau seem to experience nearly-constant oxidized mercury enhancements over the sunlit period, peaking in the summer. These unexplained events have not been recorded over the Northern Hemisphere ice cap at Summit (3600 m) in Greenland) (Faïn et al., 2008).

\section{Conclusions}

In general, the observations made in the Antarctic region constitute direct evidence of a link between sunlight-assisted $\mathrm{Hg}(0)$ oxidation, greatly enhanced atmospheric $\mathrm{Hg}(\mathrm{II})$ wet and/or dry deposition, and elevated $\mathrm{Hg}$ concentrations in the polar snow-pack. Antarctic coastal sites experience episodic mercury depletion events which occur predominantly in the late winter and early spring. However significant differences are observed on coastal areas and on the Antarctic Plateau, which is largely unexplored. This dynamic mercury cycle on the Polar Plateau appears to be driven by the snowpack photochemistry and the occurrence of fast $\operatorname{Hg}(0)$ oxidation processes. However mechanisms of reactivity are not understood. The mercury in the air over the Polar Plateau (the coldest place on Earth), unlike any other known location, is predominately $\mathrm{Hg}(\mathrm{II})$ in summer. The discovery of $\mathrm{Hg}$ reactivity on the Antarctic Plateau, and total mercury concentrations of $\sim 200 \mathrm{ng} \mathrm{L}^{-1}$ in the snowpack is a fairly new topic, and these studies open a vast area of research for the future. The fast reactivity of $\mathrm{Hg}(0)$ and the periodic occurrence of oxidized species of $\mathrm{Hg}$ in the Antarctic troposphere from late winter to summer may result in an important net input of atmospheric $\mathrm{Hg}$ into the polar surfaces. However, complex processes take place after deposition that may result in less significant net-inputs from the atmosphere since a fraction, sometimes significant, of deposited $\mathrm{Hg}$ may be recycled. The ratio between deposition onto snow pack and reemission is an important parameter that determines the net impact of AMDEs in the Antarctic environment.

The goal of this review is to provide a current view of the $\mathrm{Hg}$ chemistry in the Antarctic troposphere. It highlights the fact that $\mathrm{Hg}$ science in Antarctica is very limited, and that this continent is particularly unexplored regarding $\mathrm{Hg}$. Therefore, the contribution of this unique reactivity occurring in the Antarctic troposphere to the global budget of atmospheric $\mathrm{Hg}$ and the role played by snow and ice surfaces of these regions need further investigations, including experimental monitoring and modelling studies. The dynamic species transformations of atmospheric mercury during Antarctic spring and summer illustrate the complexity of photochemical reactions in Polar Regions and have revealed the limitations in our understanding of the chemical cycling of mercury, and other atmospheric constituents/contaminants in remote regions with seasonally variable sea-ice coverage. In order to gain a better understanding of $\mathrm{Hg}$ cycling in Antarctica, we propose the following future research directions:

- Long-term measurements of $\operatorname{Hg}(0)$ and other atmospheric $\mathrm{Hg}$ species in the Antarctic which are very limited and need to be increased. They must be put also into place at several coastal locations so that the effects of the changes to $\mathrm{Hg}$ distribution in this environment can be monitored and scrutinized.

- Measurements of deposition rates of $\mathrm{Hg}$ species in coastal environments, their post depositional fate, and their transfer to the ecosystems in order to assess the potential threat to these pristine ecosystems.

- Measurements on the Polar Plateau, where a unique reactivity and recycling of $\mathrm{Hg}$ species is observed. The measurements should combine long-term atmospheric measurements of $\mathrm{Hg}$ species together with atmospheric oxidants. The cycling of deposition/reemission might influence significantly the interpretation of ice cores. 
Therefore measurements should also include $\mathrm{Hg}$ determination in surface snow and in deeper snow layers at various locations of the Plateau in order to assess the net input of atmospheric $\mathrm{Hg}$ to the snow surfaces. The nature of diffusion of mercury species in surfaces and interfaces (i.e., snow/ice) should also be characterized.

- A significant improvement of our understanding of atmospheric chemistry and kinetics. Current understandings are based on limited laboratory and theoretical studies. Some of the reactions, involving $\mathrm{Hg}(0)$ and hydroxyl and halogen radicals for instance, are not clearly defined and reaction products are not well understood. Therefore, research activities on heterogeneous mercury reactions (theoretical, kinetic and dynamic studies) should be included as well as proper incorporation in atmospheric modeling.

- A 1-D photochemical model of the surface snow and air column which includes $\mathrm{Hg}$ and the oxidizing canopy of the polar plateau.

Acknowledgements. AD, JC, CF want to acknowledge the French Polar Institute IPEV (program Glaciologie 902) for logistical supports and the ANR VMC (VANISH) for funding.

We are grateful to Andreas Richter for providing the $\mathrm{BrO}$ map.

Edited by: K.-H. Kim

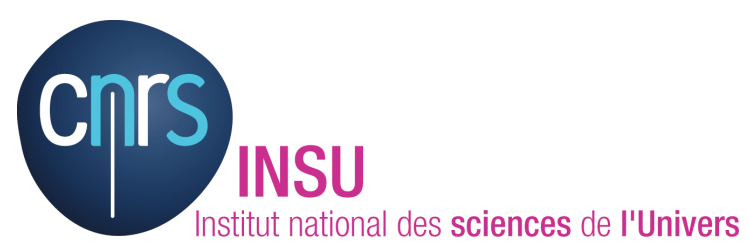

The publication of this article is financed by CNRS-INSU.

\section{References}

Arimoto, R., Schloesslin, C., Davis, D., Hogan, A., Grube, P., Fitzgerald, W., and Lamborg, C.: Lead and mercury in aerosol particles collected over the South Pole during ISCAT-2000, Atmos. Environ., 38, 5485-5491, 2004.

Aspmo, K., Gauchard, P. A., Steffen, A., Temme, C., Berg, T., Bahlmann, E., Banic, C., Dommergue, A., Ebinghaus, R., Ferrari, C., Pirrone, N., Sprovieri, F., and Wibetoe, G.: Measurements of atmospheric mercury species during an international study of mercury depletion events at Ny-Alesund, Svalbard, spring 2003. How reproducible are our present methods?, Atmos. Environ., 39, 7607-7619, 2005.

Bargagli, R., Agnorelli, C., Borghini, F., and Monaci, F.: Enhanced Deposition and Bioaccumulation of Mercury in Antarctic Terrestrial Ecosystems Facing a Coastal Polynya, Environ. Sci. Technol., 39, 8150-8155, 2005.
Bargagli, R.: Environmental contamination in Antarctic ecosystems, Sci. Total Environ., 400, 212-226, 2008.

Brooks, S., Arimoto, R., Lindberg, S., and Southworth, G.: Antarctic polar plateau snow surface conversion of deposited oxidized mercury to gaseous elemental mercury with fractional long-term burial, Atmos. Environ., 42, 2877-2884, 2008 a.

Brooks, S., Lindberg, S., Southworth, G., and Arimoto, R.: Springtime atmospheric mercury speciation in the McMurdo, Antarctica coastal region, Atmos. Environ., 42, 2885-2893, 2008b.

Calvert, J. G. and Lindberg, S. E.: A modeling study of the mechanism of the halogen-ozone-mercury homogeneous reactions in the troposphere during the polar spring, Atmos. Environ., 37, 4467-4481, 2003.

Castro, L., Dommergue, A., Ferrari, C., and Maron, L.: A DFT study of the reactions of $\mathrm{O} 3$ with $\mathrm{Hg}^{\circ}$ or $\mathrm{Br}$, Atmos. Environ., 43, 5708-5711, 2009.

Courteaud, J., Dommergue, A., and Ferrari, C.: Reactivity and speciation of mercury in Concordia Station perennial snow pack, East Antarctica, in preparation, 2010.

Davis, D. D., Seelig, J., Huey, G., Crawford, J., Chen, G., Wang, Y., Buhr, M., Helmig, D., Neff, W., Blake, D., Arimoto, R., and Eisele, F.: A reassessment of Antarctic plateau reactive nitrogen based on ANTCI 2003 airborne and ground based measurements, Atmos. Environ., 42, 2831-2848, 2008.

De Mora, S. J., Patterson, J. E., and Bibby, D. M.: Baseline atmospheric mercury studies at Ross Island, Antarctica, Antarct. Sci., 5, 323-326, 1993.

Dietz, R., Outridge, P. M., and Hobson, K. A.: Anthropogenic contributions to mercury levels in present-day Arctic animals - A review, Sci. Total Environ., 407, 6120-6131, 2009.

Dominé, F. and Shepson, P. B.: Air-Snow Interactions and Atmospheric Chemistry, Science, 297, 1506-1510, 2002.

Ebinghaus, R., Jennings, S. G., Schroeder, W. H., Berg, T., Donaghy, T., Guentzel, J., Kenny, C., Kock, H. H., Kvietkus, K., Landing, W., Muhleck, T., Munthe, J., Prestbo, E. M., Schneeberger, D., Slemr, F., Sommar, J., Urba, A., Wallschlager, D., and Xiao, Z.: International field intercomparison measurements of atmospheric mercury species at Mace Head, Ireland, Atmos. Environ., 33, 3063-3073, 1999.

Ebinghaus, R., Kock, H. H., Coggins, A. M., Spain, T. G., Jennings, S. G., and Temme, C.: Long-term measurements of atmospheric mercury at Mace Head, Irish west coast, between 1995 and 2001, Atmos. Environ., 36, 5267-5276, 2002a.

Ebinghaus, R., Kock, H. H., Temme, C., Einax, J. W., Löwe, A. G., Richter, A., Burrows, J. P., and Schroeder, W. H.: Antarctic Springtime Depletion of Atmospheric Mercury, Environ. Sci. Technol., 36, 1238-1244, 2002b.

Eisele, F., Davis, D. D., Helmig, D., Oltmans, S. J., Neff, W., Huey, G., Tanner, D., Chen, G., Crawford, J., Arimoto, R., Buhr, M., Mauldin, L., Hutterli, M., Dibb, J., Blake, D., Brooks, S. B., Johnson, B., Roberts, J. M., Wang, Y., Tan, D., and Flocke, F.: Antarctic Tropospheric Chemistry Investigation (ANTCI) 2003 overview, Atmos. Environ., 42, 2749-2761, 2008.

Faïn, X., Ferrari, C. P., Dommergue, A., Albert, M., Battle, M., Arnaud, L., Barnola, J. M., Cairns, W., Barbante, C., and Boutron, C.: Mercury in the snow and firn at Summit Station, Central Greenland, and implications for the study of past atmospheric mercury levels, Atmos. Chem. Phys., 8, 3441-3457, 2008, http://www.atmos-chem-phys.net/8/3441/2008/. 
Faïn, X., Ferrari, C. P., Dommergue, A., Albert, M. R., Battle, M., Severinghaus, J., Arnaud, L., Barnola, J.-M., Cairns, W., Barbante, C., and Boutron, C.: Polar firn air reveals large-scale impact of anthropogenic mercury emissions during the 1970s, Proc. Natl. Acad. Sci. U.S.A., 106, 16114-16119, doi:10.1073/pnas.0905117106, 2009.

Fan, S. M. and Jacob, D. J.: Surface ozone depletion in arctic spring sustained by bromine reactions on aerosols, Nature, 359, 522524, 1992.

Friess, U.: Spectroscopic Measurements of Atmospheric Trace Gases at Neumayer-Station, Antarctica, Ph.D. Thesis, University of Heidelberg, Heidelberg, Germany, 2001.

Goodsite, M. E., Plane, J. M. C., and Skov, H.: A theoretical study of the oxidation of $\mathrm{Hg}-0$ to $\mathrm{HgBr} 2$ in the troposphere, Environ. Sci. Technol., 38, 1772-1776, 2004.

Hynes, A. J., Donohoue, D. L., Goodsite, M. E., and Hedgecock, I. M.: Our current understanding of major chemical and physical processes affecting $\mathrm{Hg}$ dynamics in the atmosphere and at the airwater/terrestrial interfaces, in: Mercury fate and transport in the global atmosphere: emissions, measurements and models, edited by: Pirrone, N. and Mason, R. P., Springer, 427-457, 2009.

Jitaru, P., Gabrielli, P., Marteel, A., Plane, J. M. C., Planchon, F. A. M., Gauchard, P. A., Ferrari, C. P., Boutron, C. F., Adams, F. C., Hong, S., Cescon, P., and Barbante, C.: Atmospheric depletion of mercury over Antarctica during glacial periods, Nature Geosci., 2, 505-508, 10.1038/ngeo549, 2009.

Jones, A. E., Anderson, P. S., Wolff, E. W., Turner, J., Rankin, A. M., and Colwell, S. R.: A role for newly forming sea ice in springtime polar tropospheric ozone loss? Observational evidence from Halley station, Antarctica, J. Geophys. Res., 111, D08306, doi:10.1029/2005JD006566, 2006.

Jones, A. E., Wolff, E. W., Salmon, R. A., Bauguitte, S. J. B., Roscoe, H. K., Anderson, P. S., Ames, D., Clemitshaw, K. C., Fleming, Z. L., Bloss, W. J., Heard, D. E., Lee, J. D., Read, K. A., Hamer, P., Shallcross, D. E., Jackson, A. V., Walker, S. L., Lewis, A. C., Mills, G. P., Plane, J. M. C., Saiz-Lopez, A., Sturges, W. T., and Worton, D. R.: Chemistry of the Antarctic Boundary Layer and the Interface with Snow: an overview of the CHABLIS campaign, Atmos. Chem. Phys., 8, 3789-3803, 2008, http://www.atmos-chem-phys.net/8/3789/2008/.

Kaleschke, L., Richter, A., Burrows, J., Afe, O., Heygster, G., Notholt, J., Rankin, A. M., Roscoe, H. K., Hollwedel, J., Wagner, T., and Jacobi, H. W.: Frost flowers on sea ice as a source of sea salt and their influence on tropospheric halogen chemistry, Geophys. Res. Lett., 31, L16114, doi:10.1029/2004GL020655, 2004.

Landing, W. M., Guentzel, J. L., Gill, G. A., and Pollman, C. D.: Methods for measuring mercury in rainfall and aerosols in Florida, Atmos. Environ., 32, 909-918, 1998.

Landis, M. S., Stevens, R. K., Schaedlich, F., and Prestbo, E. M.: Development and Characterization of an Annular Denuder Methodology for the Measurement of Divalent Inorganic Reactive Gaseous Mercury in Ambient Air, Environ. Sci. Technol., 36, 3000-3009, 2002.

Legrand, M., Preunkert, S., Jourdain, B., Gallée, H., Goutail, F., Weller, R., and Savarino, J.: Year-round record of surface ozone at coastal (Dumont d'Urville) and inland (Concordia) sites in East Antarctica, J. Geophys. Res., 114, D20306, doi:10.1029/2008JD011667, 2009.
Lehrer, E.: Polar Tropospheric Ozone Loss, Ph.D. Thesis, University of Heidelberg, Heidelberg, Germany, 1999.

Lindberg, S., Bullock, R., Ebinghaus, R., Engstrom, D., Feng, X. B., Fitzgerald, W., Pirrone, N., Prestbo, E., and Seigneur, C.: A synthesis of progress and uncertainties in attributing the sources of mercury in deposition, Ambio, 36, 19-32, 2007.

Lindberg, S. E., Brooks, S., Lin, C. J., Scott, K. J., Landis, M. S., Stevens, R. K., Goodsite, M., and Richter, A.: Dynamic Oxidation of Gaseous Mercury in the Arctic Troposphere at Polar Sunrise, Environ. Sci. Technol., 36, 1245-1256, 2002.

Lu, J. Y., Schroeder, W. H., Berg, T., Munthe, J., Schneeberger, D., and Schaedlich, F.: A device for sampling and determination of total particulate mercury in ambient air, Anal. Chem., 70, 24032408, 1998.

Maron, L., Dommergue, A., Ferrari, C. P., Delacour-Larose, M., and Faïn, X.: How elementary mercury react in presence of halogen radicals and/or halogen anions: A DFT investigation, Chem.Eur. J., 14, 8322-8329, 2008.

Mauldin III, R. L., Kosciuch, E., Henry, B., Eisele, F. L., Shetter, R., Lefer, B., Chen, G., Davis, D., Huey, G., and Tanner, D.: Measurements of $\mathrm{OH}, \mathrm{HO} 2+\mathrm{RO} 2, \mathrm{H} 2 \mathrm{SO} 4$, and MSA at the South Pole during ISCAT 2000, Atmos. Environ., 38, 54235437, 2004.

McConnell, J. C., Henderson, G. S., Barrie, L., Bottenheim, J., Niki, H., Langford, C. H., and Templeton, E. M. J.: PHOTOCHEMICAL BROMINE PRODUCTION IMPLICATED IN ARCTIC BOUNDARY-LAYER OZONE DEPLETION, Nature, 355, 150-152, 1992.

Munthe, J., Wängberg, I., Pirrone, N., Iverfeldt, A., Ferrara, R., Ebinghaus, R., Feng, X., Garfeldt, K., Keeler, G., Lanzillotta, E., Lindberg, S. E., Lu, J. Y., Mamane, Y., Prestbo, E., Schmolke, S. R., Schroeder, W. H., Sommar, J., Sprovieri, F., Stevens, R. K., Stratton, W. J., Tuncel, G., and Urba, A.: Intercomparison of methods for sampling and analysis of atmospheric mercury species, Atmos. Environ., 35, 3007-3017, 2001.

Pacyna, E. G., Pacyna, J. M., Steenhuisen, F., and Wilson, S.: Global anthropogenic mercury emission inventory for 2000, Atmos. Environ., 40, 4048-4063, 2006.

Richter, A., Wittrock, F., Eisinger, M., and Burrows, J. P.: GOME observations of tropospheric $\mathrm{BrO}$ in northern hemispheric spring and summer 1997, Geophys. Res. Lett., 25, 2683-2686, 1998.

Saiz-Lopez, A., Mahajan, A. S., Salmon, R. A., Bauguitte, S. J. B., Jones, A. E., Roscoe, H. K., and Plane, J. M. C.: Boundary layer halogens in coastal Antarctica, Science, 317, 348-351, 2007.

Saiz-Lopez, A., Plane, J. M. C., Mahajan, A. S., Anderson, P. S., Bauguitte, S. J. B., Jones, A. E., Roscoe, H. K., Salmon, R. A., Bloss, W. J., Lee, J. D., and Heard, D. E.: On the vertical distribution of boundary layer halogens over coastal Antarctica: implications for O3, HOx, NOx and the $\mathrm{Hg}$ lifetime, Atmos. Chem. Phys., 8, 887-900, 2008, http://www.atmos-chem-phys.net/8/887/2008/.

Schroeder, W. H., Anlauf, K. G., Barrie, L. A., Lu, J. Y., Steffen, A., Schneeberger, D. R., and Berg, T.: Arctic springtime depletion of mercury, Nature, 394, 331-332, 1998.

Selin, N. E., Jacob, D. J., Park, R. J., Yantosca, R. M., Strode, S., Jaegle, L., and Jaffe, D.: Chemical cycling and deposition of atmospheric mercury: Global constraints from observations, J. Geophys. Res., 112, D02308, doi:02310.01029/02006JD007450, 2007. 
Simpson, W. R., Carlson, D., Honninger, G., Douglas, T. A., Sturm, M., Perovich, D., and Platt, U.: First-year sea-ice contact predicts bromine monoxide $(\mathrm{BrO})$ levels at Barrow, Alaska better than potential frost flower contact, Atmos. Chem. Phys., 7, 621-627, 2007, http://www.atmos-chem-phys.net/7/621/2007/.

Slemr, F., Brunke, E. G., Ebinghaus, R., Temme, C., Munthe, J., Wangberg, I., Schroeder, W., Steffen, A., and Berg, T.: Worldwide trend of atmospheric mercury since 1977, Geophys. Res. Lett., 30, 1516, doi:10.1029/2003GL016954, 2003.

Sprovieri, F. and Pirrone, N.: A preliminary assessment of mercury levels in the Antarctic and Arctic troposphere, J. Aerosol Sci., 31, 757-758, 2000.

Sprovieri, F., Pirrone, N., Hedgecock, I. M., Landis, M. S., and Stevens, R. K.: Intensive atmospheric mercury measurements at Terra Nova Bay in Antarctica during November and December 2000, J. Geophys. Res., 107, 4722, doi:10.1029/2002JD002057, 2002

Steffen, A., Schroeder, W. H., Bottenheim, J., Narayana, J., and Fuentes, J. D.: Atmospheric mercury concentrations: measurements and profiles near snow and ice surfaces in the Canadian Arctic during Alert 2000, Atmos. Environ., 36, 2653-2661, 2002.

Steffen, A., Schroeder, W., Macdonald, R., Poissant, L., and Konoplev, A.: Mercury in the Arctic atmosphere: An analysis of eight years of measurements of GEM at Alert (Canada) and a comparison with observations at Amderma (Russia) and Kuujjuarapik (Canada), Sci. Total Environ., 342, 185-198, 2005.
Steffen, A., Douglas, T., Amyot, M., Ariya, P., Aspmo, K., Berg, T., Bottenheim, J., Brooks, S., Cobbett, F., Dastoor, A., Dommergue, A., Ebinghaus, R., Ferrari, C., Gardfeldt, K., Goodsite, M. E., Lean, D., Poulain, A. J., Scherz, C., Skov, H., Sommar, J., and Temme, C.: A synthesis of atmospheric mercury depletion event chemistry in the atmosphere and snow, Atmos. Chem. Phys., 8, 1445-1482, 2008, http://www.atmos-chem-phys.net/8/1445/2008/.

Temme, C., Einax, J. W., Ebinghaus, R., and Schroeder, W. H.: Measurements of Atmospheric Mercury Species at a Coastal Site in the Antarctic and over the South Atlantic Ocean during Polar Summer, Environ. Sci. Technol., 37, 22-31, 2003.

Vogt, R., Crutzen, P. J., and Sander, R.: A mechanism for halogen release from sea-salt aerosol in the remote marine boundary layer, Nature, 383, 327-330, 1996.

Witherow, R. A., and Lyons, W. B.: Mercury deposition in a polar desert ecosystem, Environ. Sci. Technol., 42, 4710-4716, 2008.

Yang, X., Pyle, J. A., and Cox, R. A.: Sea salt aerosol production and bromine release: Role of snow on sea ice, Geophys. Res. Lett., 35, L16815 doi:10.1029/2008g1034536, 2008. 